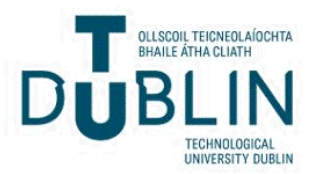

Technological University Dublin

ARROW@TU Dublin

2020-06-30

\section{Long-Term Durability of Solar Photovoltaic Modules}

\author{
Chibuisi Chinasaokwu Okorieimoh \\ Technological University Dublin, chibuisi.okorieimoh@tudublin.ie \\ Brian Norton \\ Technological University Dublin, brian.norton@tudublin.ie
}

Follow this and additional works at: https://arrow.tudublin.ie/engscheleart

Part of the Electrical and Computer Engineering Commons, Engineering Science and Materials Commons, and the Environmental Engineering Commons

\section{Recommended Citation}

Okorieimoh, C. \& Norton, B. (2019). Long-germ durability of solar photovoltaic modules. 5th. Annual Seeds Conference, 11-12 September,Ipswich, United Kingdom. DOI:10.1007/978-3-030-44381-8_24

This Conference Paper is brought to you for free and open access by the School of Electrical and Electronic Engineering at ARROW@TU Dublin. It has been accepted for inclusion in Conference papers by an authorized administrator of ARROW@TU Dublin. For more information, please contact arrow.admin@tudublin.ie, aisling.coyne@tudublin.ie,gerard.connolly@tudublin.ie. Funder: Fiosraigh

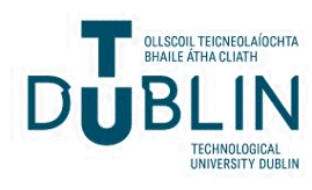




\title{
Long-Term Durability of Solar Photovoltaic Modules
}

\author{
Chibuisi Chinasaokwu Okorieimoh, Brian Norton, and Michael Conlon
}

\section{Introduction}

Solar photovoltaic cells convert solar energy into electrical energy through the photovoltaic effect. Solar energy can reduce emissions of carbon dioxide $\left(\mathrm{CO}_{2}\right)$ associated with the generation from fossil fuels as the only $\mathrm{CO}_{2}$ emissions are those embodied in their manufacture (Norton, 1999). The electricity generated by solar PV is more environmentally friendly as it is carbon-emission free at the point of generation when compared to fossil fuel generation. Solar PV panels experience long-term performance degradation resulting in lower like-per-like efficiency and performance ratios when compared with their initial performance.

Reducing rates of PV module degradation aim to maintain efficiency of solar PV systems ( $\mathrm{Li}, 2016)$. As manufacturers usually guarantee the life span of PV modules for more than 20 years ( $\mathrm{Li}, 2016)$, it is therefore necessary to track and mitigate the degradation of PV modules over this period. Both during and beyond this period knowing degradation behaviour is essential for operation, maintenance and repair. 


\section{Distinguishing Transient Performance Changes from Longer-Term Degradation}

PV module output varies with solar irradiance and module temperature. It is also affected by shading, rain and dust (Dunlop \& Halton, 2006; Tiwari, Mishra, \& Solanki, 2011). All these variations are transient on a variety of timescales and/or reversible. Degradation refers to loss of output due to physical degradation or

C. C. Okorieimoh (四) - B. Norton · M. Conlon

Dublin Energy Lab, Schoool of Electrical and Electronic Engineering, Technōlōgicăl

University Dublin, Dublin 8, Ireland

e-mail: d18125175@ mydit.ie

O Springer Nature Switzerland AG 2020

L. Scott et al. (eds.), Sustainable Ecologieal Engineering Design,

https://doi.org/10.1007/978-3-030-44381-8_24

damage to the PV cell, the effects are not reversible. It refers to effects that will ultimately require the replacement of a PV cell for the system to return to its initial performance. Transient effect caused by increase in PV cell ambient temperature can lead to reductions in output and efficiencies (Okorieimoh et al., 2019). Degradation is measured by changes mean efficiency and/or performance ratio over the long-term as illustrated indicatively in Fig. 1. It can also be observed in perturbation caused by cell failure in the current-voltage $(I-V)$ curves for an array.

This paper discusses the long-term durability of solar photovoltaic modules with particular emphasis on:

1. How to achieve long-term durability of solar photovoltaic modules

2. What affects the durability of solar photovoltaic modules

3. What are the remedies to solar photovoltaic (PV) degradation

4. How the durability and reliability of PV modules can be improved 
Individual module degradation can be attributed to intrinsic property changes in the PV máterials caused by extemal effects such as (a) potential induced dégradation (PID) (Pingelet al., 2010) and (b) light induced degradation (LID) (Sopori et al., 2012).

The outdoor operation of cells as part of a module in an array means mechanisms external to solar cell such as corrosion in interconnections and solder bonds play a significant role in performance degradation $(\mathrm{Li}, 2016)$. This makes it important to determine the degradation rates under outdoor operational conditions rather than indoor testing of isolated modules. $\mathrm{Li} \mathrm{(2016)}$ classified the major difficulties in evaluating degradation rates of PV modules from real operational data into:

1. Large fluctuations of the operational data due to uncontrollable external parameters such as weather conditions like solar radiation, rain, eloud movement, wind velocity and ambient temperature together with unexpected changes of factors external to PV systems such as unexpected shading, inverter problems and control failures.

2. Systematic 'degradation' in the measurement of PV module operational performance caused by control sensor drifting with time as a result of electronic ageing of components such as thé drifting of irradiancé sensors. The energy output of a PV system depends on weather conditions (Osterwald, Anderberg, Rummel, \& Ottoson, 2002), (Tiwari et al., 2011), (Li, Prawiradiraja, \& Battul, 2013).

Fig. 1 Degradation on solar PV system

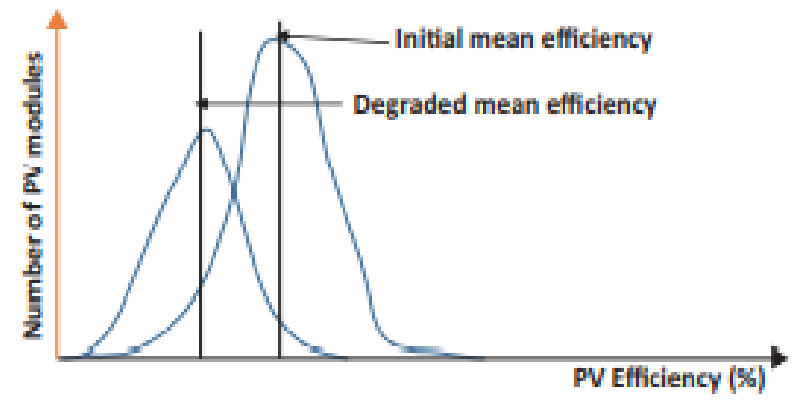


According to Qsterwald et al. (2002), the degradation rate of silicon PV modules is around $-0.7 \%$ per year of maximum power rating.

\section{Degradation Rates}


the following types of PV modules: monocrystalline silicon (m-Si) (such as glassback sheet with frame and glass-glass without frame), heterojunction crystalline silicon, monocrystalline silicon back-contact, multi-crystalline silicon, doublejunction "micromorph" silicon, single-junction/double-junction amorphous silicon (a-Si), cadmium telluride (CdTe), and copper indium gallium diselenide (CIGS) as seen in Fig. 2, 3 years outdoor monitoring data showed the degradation paths of each module.

Statistical decomposition techniques were used to draw out paths for the performance ratio $(Y K)$, short-circuit current $\left(I_{\mathrm{sc}}\right)$, open-circuit voltage $\left(V_{\mathrm{Oc}}\right)$, and fill factor $(\mathrm{FF})$. Degradation rates for the monocrystalline silicon $(\mathrm{m}-\mathrm{Si})$ modules were found to be equal to or less than $-0.8 \%$ per year as a result of the decrease in $I_{\mathrm{SC}}$. Multi-crystalline silicon modules exhibited a higher degradation rate of $-1.0 \%$ per year. The a-Si, micromorph silicon and CdTe modules showed a degradation rate of about $-2 \%$ per year. The CIGS module showed a degradation rate of $-6 \%$ per year higher than CdTe.

The study of annual degradation rates of recent crystalline silicon photovoltaic modules were carried out by Tetsuyuki and Atsushi (2017). Six crystalline silicon PV modules connected to an electric power grid were analysed. Three indicators were used for the annual degradation rates of the different crystalline silicon

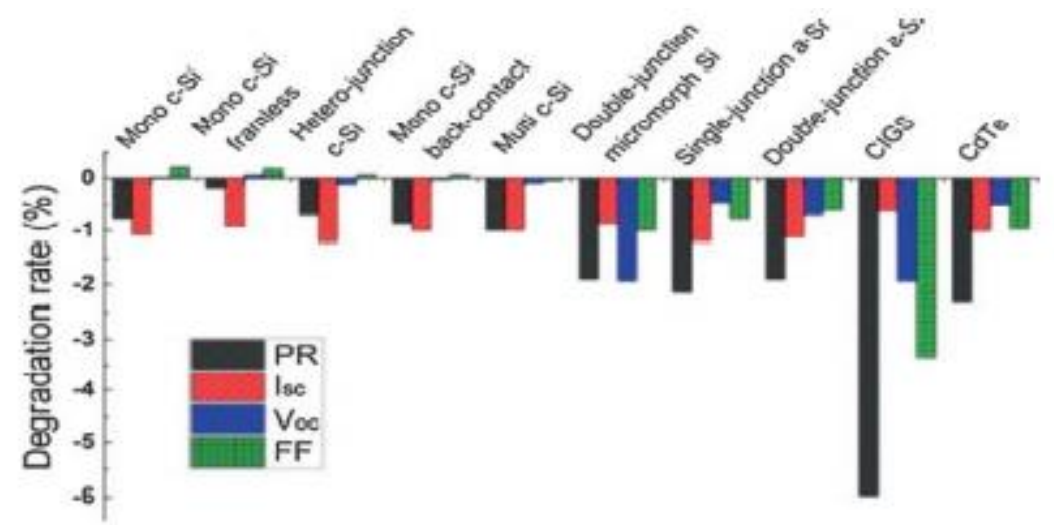

Fig. 2 Mean annual degradation rates $(\%)$ of performance ratios (PRs) and the $l-V$ curve components: short-circuit current $\left(I_{\infty}\right)$, open-circuit voltage $\left(V_{\infty}\right)$, and fill factor (FF) for tea module types (Jia et al., 2014) 
PV: energy yield, performance ratio and indoor power. The performance of the module was evaluated from electricity output measurements taken over 3 years. The following trends were found in the three indicators; energy yield: $0.0,-0.4 \%$ per year, $0.0,0.1 \%$ per year, $1.5 \%$ per year and $0.5 \%$ per year, performance ratio: 0.0 , $-0.4 \%$ per year, $-0.1 \%$ per year, $0.0,1.4 \%$ per year and $0.5 \%$ per year and indoor power: $0.1 \%$ per year, $-0.3 \%$ per year, $0.2 \%$ per year, $0.0,0.7 \%$ per year and $0.6 \%$ per year were similar. The performance of the newly installed PV modules were found to decrease by over $2 \%$ as a result of initial light-induced degradation (LID) after installation (Tetsuyuki \& Atsushi, 2017).

The power output of an outdoor PV module has been shown to reduce as a result of thermal cycling causing crack formation between solders and metals (Nochang, Jaeseong, \& Changwoon, 2014). Dunlop and Halton (2006) studied degradation of PV modules in outdoor conditions for 22 years. They monitored the electrical power outputs of monocrystalline silicon, polycrystalline silicon and amorphous silicon modules. They found 8-12\% decrease of maximum power output of the PV modules $\left(P_{\max }\right)$ after 20 years outdoor exposure. Their research showed that about $80 \%$ of the reduction was due to corrosion and the remaining $20 \%$ was attributed to dust accumulating on the PV modules.

An experimental study of degradation modes and their effects on photovoltaic module was conducted after 12 years of field operation (Saadsaoud, Ahmeda, Er, \& Rouabah, 2017). Their investigation found that degradation led to annual reductions in output power ranging between $2.08 \%$ and $5.2 \%$. Short circuit current $\left(I_{s c}\right)$ reduced by between $2.75 \%$ and $2.84 \%$ annually. The open-circuit voltage $\left(V_{0<}\right)$ was found to be the least affected, with annual reductions ranging between $0.01 \%$ and $4.25 \%$.

\section{Degradation Influences}

The existence of only one highly degraded PV module in a PV system reduces daily

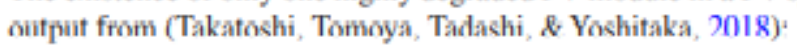

1. $19.8 \mathrm{kWh}$ to $18.7 \mathrm{kWh}$ during sunny days

2. $11.3 \mathrm{kWh}$ to $10.8 \mathrm{kWh}$ during partly cloudy sunny days

3. $5.5 \mathrm{kWh}$ to $5.3 \mathrm{kWh}$ during cloudy days

Pramod, Tiwari, Sastry, Birinchi, and Vikrant (2016) investigated degradation of mono-crystalline photovoltaic modules after 22 years of outdoor exposure. They studied 90 mono-crystalline silicon PV modules installed on the rooftop of the National Institute of Solar Energy (NISE) near New Delhi, India, after 22 years of outdoor operation. They carried out visual inspection, thermal imaging, currentvoltage characteristic curve analysis and insulation resistance measurement and in addition calculation of the degradation rate. The mean power reduction rate of $90 \mathrm{PV}$ modules over the period of 22 years was found to be about $1.9 \%$ per year at a peak rate of power reduced by $4.1 \%$ per year and the minimum rate of power reduction was $0.3 \%$ per year. The result of electrical resistance of insulation measurements of $90 \mathrm{PV}$ 
Fig. 3 Degradation rates for different electrical parameters (Pramod et al. 2016), where $l_{\text {sc }}$ shortcircuit current; $V_{\text {oce }}$ open-circuit current; $P_{t}$ maximum power and FF fill factor

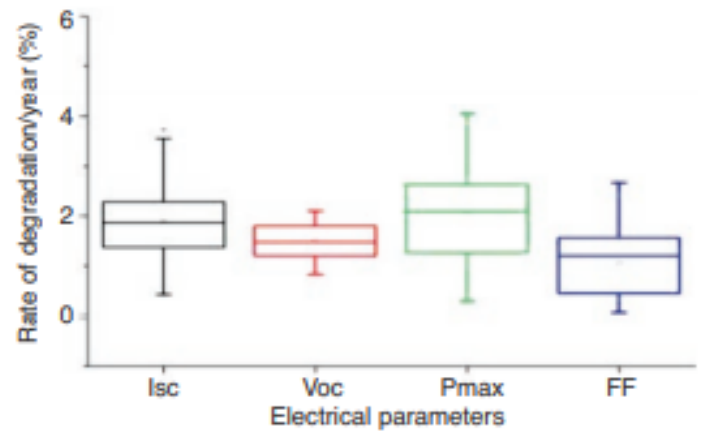

modules (both in dry and wet conditions) showed that only 2 PV modules showed insulation electrical resistance of less than $400 \mathrm{M} \Omega$ in dry conditions. Analysis of electrical parameters shown in Fig. 3 indicated that there was degradation of short circuit current, from $0.4 \%$ to $3.7 \%$ per year with a mean value of $1.8 \%$ per year. The open circuit voltage ranged from $0.8 \%$ to $2.1 \%$ per year with a mean value of $1.4 \%$ per year and fill factor ranged from $0.7 \%$ to $2.6 \%$ per year with a mean value of $1 \%$ per year. The maximum power $P_{\max }$ reduction rate ranges from $0.3 \%$ to $4.1 \%$ per year with a mean value of $1.9 \% / y e a r$. The reduced power output was mainly due to the degradation in short circuit current.

\section{Diagnosis of Degradation Mechanisms}

The reliability and degradation of solar PV modules was investigated by David, Muyiwa, Gabriel, and Isaac (2017) as part of a case study of polycrystalline modules in Ghana. Fourteen polycrystalline modules were installed on the concrete roof in a hot humid environment. They were evaluated after continuous outdoor exposure for 19 years. They used a visual inspection checklist to document the physical state of the modules. The PV modules were also evaluated by current-voltage $(I-V)$ characterization and thermal imaging. Their results showed that the modules were found to be in good physical state with the exception of some bubbles developing on the front side. There was insignificant corrosion found at the edge of the cells. The performance change of the PV modules over the exposure duration was: nominal power, $21 \%$ to $35 \%$; short circuit current, $5.8 \%$ to $11.7 \%$; open circuit voltage, $3.6 \%$ to $5.6 \%$ and $11.9 \%$ to $25.7 \%$ for fill factor, respectively.

Zhengpeng, Timothy, and Armin (2011) carried out a study on PV module durability under high voltage biased damp hot and humid conditions. They made use of ten photovoltaic module technologies which comprisal (a) five thin-film technologies and (b) five silicon wafer based technologies. The PV modules were subjected to accelerated ageing tests in a climate dark chamber under temperature conditions of $85^{\circ} \mathrm{C}$ and relative humidity of $85 \%$ and electrical bias for a period of $650 \mathrm{~h}$ 
(27 1/12 days). They applied a bias voltage of $\pm 1000 \mathrm{~V}$ DC between the active circuit of each module and the module frame. Their results showed biased stressing conditions in damp heat could significantly degrade the electrical performance and cause several defects including delamination, glass surface deterioration, frame corrosion, and metal grid discoloration, depending on module type and bias polarity.

PV modules can be damaged by weather, temperature variations, soiling effect and ultraviolet exposure. Typical faults are summarized in Table 1. Performance monitoring of PV systems aims are to maintain the power output from PV systems, thus increasing economic viability (Parveen \& Saurabh, 2019). To evaluate the degradation of PV modules, Parveen and Saurabh (2019) suggested a clustering-based technique with different arrangements. They estimated the performance ratio (PR) of the PV modules without physical inspection on-site, making the suggested model useful for real-time estimation of PR This may, in turn, lead to stronger forecasting of PV array power output. Their model calculated the degradation in output solar power for amorphous silicon (a-Si), polycrystalline silicon (p-Si), and silicon hetero-junction with an intrinsic thin layer ( $\mathrm{Si}-\mathrm{HIT}$ ) over 3 years. The degradation rate for a-Si was lowest at $0.85 \%$ per year, and was highest for Si-HIT technology at between $0.95 \%$ and $2.03 \%$ per year. Their results showed good agreement with the standard procedure used for performance evaluation in a similar earlier study, but as data was taken from a range of other studies, furthers corrections for environmental factors may be necessary. Therefore, the suggested model has an advantage over other methods that real-time estimation is possible as it does not require physical inspection and imaging.

Tó create a PV panel simulation which is effective under changed environmental conditions, Murari et al. (2017) developed a model using MATLAB of an equivalent circuit. This allowed them to perform joint simulation of a PV device with power electronics interfaces. Such simulations allow optimization of the design of solar arrays and power systems.

Table 1 Typical faults associated with PV modules

\begin{tabular}{l|l}
\hline $\begin{array}{l}\text { Manufacturing } \\
\text { defects }\end{array}$ & $\begin{array}{l}\text { - Hot spots (bad soldering) (Kuitche, Pan, \& Tamizhmani, 2014); } \\
\text { - Micro-cracks "snail trail" (Köntges et al., 2008); } \\
\text { - Contamination (discolouration) (Köntges et al_, 2008) }\end{array}$ \\
\hline $\begin{array}{l}\text { Installation faults } \\
\text { (PVTRIN, 2011) }\end{array}$ & $\begin{array}{l}\text { - Incorrect design of the PV system; } \\
\text { - Low inverter and module ventilation; } \\
\text { - Loosc or very tight cables; } \\
\text { - Sensors placed badly; } \\
\text { a Lack of lightening protection; } \\
\text { - Actions that lead to corrosion }\end{array}$ \\
\hline Degradation & $\begin{array}{l}\text { - Connection issues with solder bonds (Li, 2016); } \\
\text { - Sensor drifting and packaging of materials (Li, 2016); } \\
\text { - Delamination (Zhengpeng et al., 2011); } \\
\text { - Micro-cracks (Köntges et al.. 2008) }\end{array}$ \\
\hline Catastrophic failure & $\begin{array}{l}\text { - Fire outbreak; } \\
\text { - Failing of tree branches }\end{array}$ \\
\hline
\end{tabular}


Spagnolo, Del Vecchio, Makary, Papalillo, and Martocchia (2012), Krenzinger and De Andrade (2007), Buerhop, Schlegel, Niess, and Vodermayer (2011) King, Kratochvil, Quintana, and McMahon (2000) and Ancuta and Cepisca (2011) have stated that observations using imaging methods, such as infrared (IR) themography, are valuable tools for inspecting PV-plants. This method is efficiently relevant to inaccessible roof mounted PV systems as well as to extended field plants because it is fast, reliable, contact free, non-destructive and involves measurements during operating conditions but requires no clouds and no wind. Many infrared (IR) based analysing methods are used to investigate PV modules (Breitenstein. Rakotoniaina. \& Al Rifai, 2003). Another method for image failure of PV modules is electroluminescence (Johnston, Call, Phan, \& Ahrenkiel, 2009). Köntges et al. (2008), for instance, employed this method in order to analyse the influence of micro-cracks in PV modules on power loss.

Buerhop-Lutz and Scheuerpflug (2015) inspected PV-plants using an aerial, drone-mounted infrared thermography system. They carried out their measurement using an unpiloted drone (Multikopter), a lightweight infrared (IR)-camera PI 450 (Optris), a visible camera GoPro and equipment for navigation. They presented frequently detected failure modes of installed PV modules by focusing on crystalline modules from residential and industrial roofs as well as from solar parks in the field.

\section{Concluding Observations}

When a PV module maintains acceptable efficiency for a long duration:

- More energy are produced over a module life.

- The installation is more economically viable as the same initial cost provides for a longer period of energy generation.

- Manufacturers and/or installers have lower outlays to satisfy insurance of performance guarantees.

- Inspection and maintenance costs are lower.

- Enhanced reliability provides more inherent resilience to electricity generation.

- The expected warranty of 20-25 years is assured.

- There is less environmental impact as the rate of $\mathrm{P} v$ module disposal is reduced.

When installed PV system costs were high, electricity (market interventions such as feed-in tariffs) were made. They encourage take-up by providing favourable revenue for electricity sold to the grid. They also paid-back the cost of installation, usually in less than 20 years (McCormack \& Norton, 2013). As PV generated electricity prices reach grid-parity, the need for such market interventions is obviated. The drivers underlying PV generation are also changing; there is greater interest in PV electricity self-consumption and in security of electrical supply (CastilloCagigal et al., 2011). Both the latter require assured long-term PV performance; thus understanding factors determining durability and reliability of PV systems will

become more important in initial design. This is also likely to lead to innovations in diagnostics in system operation. 


\section{References}

Ancuta, F. \& Cepisca, C. (2011). Fault analysis possibilities for PV panels. Proceedings of the 3rd International Youth Conference on Energetics (TYCE), pp. 1-5.

Breitenstein, O., Rakotoniaina, J. P., \& Al Rifai, M. H. (2003). Quantitative evaluation of shunts in solar cells by lock-in thermography. Progress in Photovoltaics: Research and Applications, 11, 515-526. https://doi.ong/10.1002/pip.520

Buerhōp, C., Schlegél, D., Nieš, M., \& Vodermayer, C. (2011). Quälity conitrol of PV-módules in the field using infrared-thermography. Proceedings of the 26th PVSEC, Hamburg, Germany, pp. 3894-3897. https://doi.org/10.4229/26thLUIVSLC201 1-5AO.5.2.

Buerhop-Lutz, C. L., \& Scheuerpflug, H. (2015). Inspecting PV-plants using aerial, drone-mounted infrared thermography system. Proceedings of the $3 \mathrm{nd}$ South African Solar Energy Conference, 3, 422-429. http://hdl.handle.net/2263/49538

Castillo-Cagigal, M., Caamano-Martin, E., Matallanas, E., Masa-Bote, D., Gutierrez, A., Monasterio-Huelin, F., \& Jimenez-Leube, J. (2011). PV self-consumption optimisation with storage and active DSM for the residential sector. Journal of Solar Energy, 85(9), 2338-2348.

David, A. Q_, Muyiwa, A. S., Gabriel, T., \& Isaac, A. E. (2017). Reliability and degradation of solar PV modules-case study of 19-year-old polycrystalline modules in Ghana. Technologies, 5, 22. https:/doi.org/10.3390/technologies5020022

Dunlop, E. D., \& Halton, D. (2006). The performance of crystalline silicon photovoltaic solar modules after 22 years of continuous outdoor exposure. Progress in Photovoltaics, 14(1), 53-64. https://doi.org/10.1002/pip.627

Jia, Y. Y., Thomas, R., Armin, G. A., \& Timothy, M. W. (2014). Performance degradation of various PV module technologies in tropical Singapore. IEEE Journal of Photovoltaics, 4(5), 1288 1294. https://doi.org/10.1109/JPHOTOV.2014.2338051

Johnston, S.W., Call, N.J., Phan, B., \& Ahrenkiel, R.K. (2009). Applications of imaging techniques for solar cell characterization. Proceedings of the 34th IEEE, Photovoltaic Specialists Conference (PVSC), pp. 000276-000281. doi:https:J/doi.ong/10.1 109/PVSC.2009.5411681

King, D. L., Kratochvil, J. A., Quintana, M. A. \& McMahon, T. J. (2000). Applications for infrared imaging equipment in photovoltaic cell, module, and system testing. Proceedings of the Twenty-Eighth IEEE Photovoltaic Specialists Conference, 2000, 1487-1490. https://doi. org/10.1109/PVSC.2000.916175

Köntges, M., Kunze, I., Naumann, V., Richter, S., Hagendorf, C., Berghold, J., \& Roericht, M. (2008). Snail tracks, worm marks and cell cracks. Photovoltaic power systems programme. IEA International Energy Agency. 7-8, 36-40.

Krenzinger, A., \& De Andrade, A. C. (2007). Accurate outdoor glass thermographic thermometry applied to solar energy devices. Joumal of Solar Energy, 81, 1025-1034.

Kuitche, J., Pan, R., \& Tamizhmani, G. (2014). Investigation of dominant figures modes for fieldaged c-Si modules in desert climatic conditions. IEEE Jouernal of Photovoltaics, 4, 814-826.

Li, X., Prawiradiraja, T. P., \& Battul, D. (2013). The role of humidity in energy output of solar panels in coastal regions. GSTF Journal of Engineering Technology, 2, 72-76.

Li, X. Y. (2016). Degradation analysis of photovoltaic modules based on operational data: effects of seasonal pattem and sensor drifting. IOP Conference Series: Earth and Envinonmental Science, to, 012063. htips://dui.ung/10.1088/1753-1315/40/1/012063

McCormack, S. J.. \& Norton. B. (2013). In E. Michalena \& J. M. Hills (Eds.). The shadows casi by inadecuaue energy governance: Why more sun does nov necessurily mean more phoiv- 
voltaic electricity, in remewable energy governance: Challenges and insecurities. Heidelhery: Springer-Verlag.

Murari, L. A. Pradip, K. S., Sounya, D., Biplah, S., Anagh, G., Arvind, P., \& Biswas, R. (2017). An improved approsch to design a photovoltaic panel. Indonevian Joumal of Electricat Engineering and Computer Science, 5(3), 515-520. https-//doi.org/10.11591/jieecs.v5.i3. pp5 $15-520$

Nochang, P. Jaeseong. J., \& Changwoon, H. (2014). Estimation of the degradation rate of multi-crystalline silicon photovoltaic module under thermal cycling stress. Microelectmonics Retiabiling, 54, 1562 https-//doi.org/l0.1016/jmicrorel.2014.03.021

Norton, B. (1999). Renewable electricity what is the true cost? Power Engineering Journal, 13, 6-12.

Okorieimoh, C. C., Norton, B., \& Conlon, M. (2019). Effect of transient performance changes on photovoltaic modules output. I0th Annual Graduate Research School Symposium, Tectmological University Dublin, Ireland. https://doi.ong/10.13140NRG.2.2.28516.94083.

Osterwald, C.R.,Anderberg, A. Rummel, S., \& Otoson, L. (2002). Degradation analysis of weath: ered crystalline silicon PV modules. Proceedings of the 29th IEEE Photovoltaic Specialist Conference, pp. 1392-1395. Retrieved from bitp://www.ostigov/bridge

Parveen, B., \& Saurabh, B. (2019). Clustering-based computation of degradation rate for photovoltaic systems. Journal of Renewable and Sustainable Energy, 11(1), 014701. https://doi. $\operatorname{org} / 10.10631 .5042688$

Pingel, S., Frank, O., Winkler, M., Daryan, S., Geipel, T., Hoehne, H., \& Berghold, J. (2010). Potential induced degnadation of solar cells and panels Proceedings of the 35th IEEE Photowoltaic Specialist Conference. pp. 2817-2822.

Pramod, R. Tiwari, G. N.. Sastry, O. S, Birinchi, B. \& Vikrant, S. (2016). Degradation of monocrystalline photowoltaic modules after 22 years of outdoor exposure in the composite climate of India. Journal of Solar Energy, 135, 786-795. hitps//doi.org/10.1016/j.solener.2016.06.047 PVTRIN. (2011). WP2 D2.6 catalogue of common failures and improper practices on PV instal. lations and maintenance ver 1, EPIA, created June 2011.

Saadsaoud, M. Ahmeda, A. H. Er, Z, \& Roumbah, Z (2017). Experimental study of degradation modes and their effects on reliability of photovoltaic modules after 12 years of field operation in the steppe region. Special issue of the 3rd International Conference on Computational and Experimental Science and Engineering (ICCESEN 2016). Journal of Acta Phvsica Polonica A. 132, 3-11. htpx://doi.org/10.12693/APhysPoLA.132.930

Supori, B., Basnyat, P., Shet, S., Mehta, V., Binns, J., \& Appel, J. (2012). Understanding light induced degradation of c-Si solar cells. Proceeding of the IEEE Photovoltaic Specialist Conference. pp. 5200-54200.

Spagnolo, G.S., Del Vecchio, P., Makary, G. Papalillo, D. \& Martocchia, A. (2012). A review of IR thermography applied to $P V$ systems. Proceedings of the Environment and Electrical Engineering (EEEIC). I th International Conference, pp. 879-884.

Takatoshi, H, Tomoya, N. Tadasthi, T, \& Yoshitaka, 1. (2018). Influence of degradation in units of PV modules on electric power autput of PV system. Journal of International Council ou Electrical Erginecring.,841), 118-126. https//doi.ong/10.1080/22348972.2018.1477095

Tetsayuki, L. \& Atsushi, M. (2017). Annual degradation rates of recent crystalline silicon photovoltaic modules. Progress in Photovoltaics: Research and Applications, 25, 953-967. hitps:// doi.org/10.1002/pip. 2903

Tiwari, G. N.. Mishra, R. K. \& Solanki, S. C. (20I1). Photovoltaic modules and their apolications: A review on thernal modelling. Applied Enengy, 88, 2287-2304.

Zhengpeng, X., Timothy, M. W, \& Armin, G. A. (2011). PV module durability testing under high voltage biased damp heat conditions. Energy Procedia, 8, 384-389. Retrieved from www. sciencedirect.com 